\title{
Hydropeaking indicators for characterization of the Upper-Rhone River in Switzerland
}

\author{
T. Meile $\cdot$ J.-L. Boillat $\cdot$ A. J. Schleiss
}

Received: 27 July 2009/Accepted: 7 June 2010/Published online: 25 June 2010

(C) Springer Basel AG 2010

\begin{abstract}
River channelization and the construction of high-head storage schemes have been the basis of agricultural and socio-economic development in many alpine regions. One example is the Upper-Rhone River in Switzerland. The Upper-Rhone's morphology changed considerably between 1863 and 1960 as a result of two major channelizations and, from 1950 on, the construction of a large number of high-head storage hydropower schemes in the catchment. These modifications have brought large benefits to the local population, at the cost, however, of substantial disturbances in aquatic and terrestrial ecosystems in and along the river. A primary factor behind these disturbances is the alteration of the natural flow regime, namely hydropeaking due to the operation of the high-head storage hydropower plants. For sustainable river-restoration projects on regulated rivers, scientists and engineers now widely accept the necessity of integrated management of the river. Different aspects such as river morphology, sediment management, water quality, temperature, and the naturally variable flow regime should be considered simultaneously. Mitigation of non-natural, subdaily flow fluctuations due to hydropeaking is a crucial step in restoring natural flow regimes, but is especially challenging due to the economic constraints such mitigation places upon hydropower plants. With the goal of addressing this challenge, this paper proposes three indicators to describe the flow regime of rivers in alpine catchments
\end{abstract}

T. Meile $\cdot$ J.-L. Boillat $\cdot$ A. J. Schleiss $(\square)$

Laboratory of Hydraulic Constructions, Ecole Polytechnique Fédérale de Lausanne, Station 18, 1015 Lausanne, Switzerland e-mail: anton.schleiss@epfl.ch

Present Address:

T. Meile

HydroCosmos SA, Grand-Rue 43, 1904 Vernayaz, Switzerland with and without high-head storage hydropower plants. The indicators quantify: (1) the seasonal distribution and transfer of water, (2) sub-daily flow fluctuations, and (3) the intensity and frequency of flow changes. Indicators are evaluated in a case study of the Upper-Rhone River for preand post-impact situations, and the benefit of a multipurpose project reducing hydropeaking on hydrologic conditions is quantified. Furthermore, the paper explores the possibility of using these indicators to link aquatic and terrestrial ecosystem well being to their hydrology.

Keywords Hydropeaking - Rapid flow ramping · Natural and altered flow regime - Hydro-ecology · Hydrological indicators - Hydropeaking mitigation . Storage power plants

\section{Introduction}

High-head storage hydropower schemes with large dams were mainly developed and erected in the Alps between 1950 and 1980. These hydropower plants contribute more than 55\% (Truffer et al. 2001; Schleiss 2007) of the electricity supply to alpine countries such as Switzerland. Due to water storage in reservoirs and water diversions into headrace tunnels, the discharge and sediment transport regimes downstream of dams are significantly altered (Zwahlen 2003). Additionally, as these high-head hydropower plants primarily operate their turbines during periods of high energy demand, the downstream flow regime of the rivers is further altered by hydropeaking.

River channelizations have been employed in many alpine valleys since the nineteenth century prior to the construction of high-head storage hydropower schemes for flood protection and floodplain encroachment to provide 
space for agriculture and infrastructure. Nevertheless, in the last 2 decades high floods have caused catastrophic damage in many alpine regions. These disasters have revealed deficiencies in flood protection in populated alpine valleys (DETEC 2008). Contemporaneous flood protection projects are reclaiming adjacent riparian lands in order to improve flood evacuation and dissipation as well as to improve channel morphology. Restoring altered and regulated flow regimes to more natural states may be additionally productive initiatives to improve ecological function and channel morphology. From an ecological point of view, flow regime is of central importance in sustaining the ecological integrity of rivers (Poff et al. 1997; Jungwirth et al. 2002; Bunn and Arthington 2002), and the restoration of river morphology is most effective if flow regime can also be improved (Unfer et al. 2004). However, unless clear benefits to ecosystem function can be identified, socio-economic constraints often limit the extent of restoration (Petts 1996; Jungwirth et al. 2002).

The aim of this article is to characterize the flow regime and quantify its deviation due to seasonal water transfer and hydropeaking from the unaltered (natural) state. The three proposed indicators apply, in particular, to alpine catchments with and without high-head storage hydropower schemes. The indicators are complementary to existing methods (Richter et al. 1996; Black et al. 2005) and they can be used: (1) to highlight and quantify differences between historical (unregulated) and current flow regimes in alpine rivers influenced by high-head storage schemes, (2) to link ecosystem function and state to alterations in flow regimes, and (3) to demonstrate positive effects of hydropeaking mitigation measures on the flow regime. The indicators are illustrated with a case study on the Upper-Rhone River, Switzerland.

\section{Problematic nature of hydropeaking}

Hydropeaking corresponds to rising or falling discharges caused either by the turning on or off of hydro-turbines (Gore 1985). River hydrology is altered due to unnatural, rapid and significant fluctuations in discharge, which result also in unnatural changes in hydraulic parameters such as water level, flow velocity and bed shear stress.

Setting aside water quality and river morphology, hydropeaking effects on its own affects almost all living organisms in a river ecosystem (Pellaud 2007). Hydropeaking negatively affects benthic macroinvertebrates (e.g. Brittain and Saltveit 1989; Céréghino and Lavandier 1998), fish populations (e.g. Cushman 1985; Freeman et al. 2001), periphyton and mosses (e.g. Brittain and Saltveit 1989), and aquatic macrophytes and riverbank vegetation (Vibert 1939). The negative effects of hydropeaking have been documented since the late 1930s (Vibert 1939). Literature reviews on the effects of hydropeaking (e.g. Baumann and Klaus 2003; Cushman 1985; Pellaud 2007) report the stranding of macroinvertebrates due to rapid ramping and the increase in catastrophic drift (e.g. Céréghino and Lavandier 1998; Céréghino et al. 2002) during sudden increases in discharge, water levels and flow velocities. These unnatural flow variations generally diminish biomass and richness of species and alter the composition of the macroinvertebrates community. In addition to biomass decreases, several studies have reported a change in abundance and composition of adult fish (Pellaud 2007). Juvenile fish are further endangered by drift and stranding in off-channel areas and exposed depositional features during water-level decreases (e.g. Baumann and Klaus 2003; Cushman 1985; Saltveit et al. 2001). Stranding experiments with juvenile brown trout by Halleraker et al. (2003) revealed a relationship between stranding and habitat quality, fish size, season, and ramping rates, as well as habituation to repeated dewatering. Gentle flow ramping slower than $10 \mathrm{~cm} / \mathrm{h}$ drastically decreases stranding of juvenile fish. Ramping rates of less than $5 \mathrm{~cm} / \mathrm{h}$ are naturally observed dewatering rates after flood events in alpine/ northern rivers. Habituation is linked to the period of stable flow prior to dewatering. A tendency towards increased stranding is observed for long habituation periods (Halleraker et al. 2003).

Despite an increasing scientific body of literature investigating the interactions between hydropeaking and riparian ecology, capabilities to quantify, correlate and predict biological responses to hydropeaking remain tenuous. The complex riparian ecosystem responses driven by altered flow and sediment regimes result in adjustments to channel morphology (and the resulting habitat) over many decades or centuries. The current metrics used to link and measure bio-physical processes are still rudimentary and lack the spatial and temporal complexity to provide a fully integrated predictive capacity of the effects of hydropeaking.

Despite the shortcomings of measuring and linking biophysical processes, it is commonly accepted that anthropogenic flow alterations are one of the main reasons for the declining health of rivers (Poff et al. 1997, 2010). The need of further efforts for linking bio-physical processes, to establish environmental flow requirements and to mitigate effects of hydropower generation by involving relatively small production losses has been recently outlined in detail by Arthington et al. (2010), Poff et al. (2010) and Malm Renöfält et al. (2010). The natural flow regime of a river can be altered by numerous human activities such as land use, drainage, deforestation, diversion of water and operation of hydropower plants. Richter et al. (1996) proposed 32 Indicators of Hydrologic Alteration (IHA) organized 
into five groups, which can be applied to pre- and postimpact flow regime situations. Olden and Poff (2003) reviewed 171 different hydrologic indices including the commonly used IHA indicators. With the help of principal component analysis, they showed that many of the known hydrologic indices are correlated. For most of the stream types, more than $90 \%$ of the total discharge variation could be explained by a few statistically significant principal components. They thus suggested that the selection of appropriate indices (based on quantitative and intuitive experience) could be used to address specific ecological questions. However, all hydrological indices reviewed by Olden and Poff (2003) are based upon daily mean discharges. They do not address indices for cases where more frequent discharge fluctuations such as hydropeaking are present.

In cases of hydropeaking where multiple peaks are generated on a daily basis, higher temporal resolution data is required. Sub-daily flow fluctuations can be taken into account by the methods offered by Archer and Newson (2002) and by Baker et al. (2004)'s Richards-Baker Flashiness Index. Black et al. (2005) developed a method for classifying alteration of the river flow regime for the European Community Water Framework Directive (EC 2000). Sub-daily flow variations are considered to drop down the hydrological regime classification by one class if they exceed $25 \%$ of the un-impacted $95 \%$ exceedance flow (Black et al. 2005).

\section{Method for flow regime analysis}

The monthly Pardé-coefficients (Weingartner and Aschwanden 1992; Pardé 1933) are used to describe the annual distribution in discharge. Pardé-coefficients are defined as the mean monthly discharge divided by the mean annual discharge:

$\mathrm{PC}_{m, a}=\frac{Q_{\text {mean month }} \quad m, a}{Q_{\text {mean annual }} \quad a}$

where $m$ is defined as the month $(1 \leq m \leq 12)$, and $a$ as the year. Since mean monthly discharges are used, this coefficient corresponds to the first group of IHA statistics and the deviation/alteration of this indicator can be determined according to Richter et al. (1996). For the hydrological and meteorological conditions found in Switzerland, Weingartner and Aschwanden (1992) identified 16 types of flow regimes ranging from glacier melt to rainfall types.

Our paper proposes that the sub-daily flow fluctuations be expressed by the difference between the maximum $\left(Q_{\text {max }, j}\right)$ and the minimum $\left(Q_{\min , j}\right)$ daily discharge. This value is normalized by the mean daily discharge $\left(Q_{\text {mean }, j_{j}}\right)$ to account for differences in river and catchment scales. This normalization is also reasonable since in a typical river reach, variation in flow characteristics (namely velocities, flow depths and shear stress) depends on both the change in discharge and the mean flow. The sub-daily flow fluctuations are then considered as the first hydropeaking indicator $\mathrm{HP}_{1}$ defined as:

$\mathrm{HP}_{1, j}=\frac{Q_{\max , j}-Q_{\min , j}}{Q_{\text {mean }, j}}$

where $j$ is the day $[1 \leq j \leq 365(366)]$.

This daily indicator changes as a function of season and meteorological conditions, as well as the operation of hydropower plants. Monthly averaged values of $\mathrm{HP}_{1}$ can then be applied as a function of time in order to investigate seasonal and annual trends.

The flow-ramping rate $\left(\mathrm{HP}_{2}\right)$ describes the gradient in flow change and is used as the second hydropeaking indicator. It is defined as the change in discharge between two successive discharge observations divided by the observation time interval as defined by:

$\mathrm{HP}_{2, i}=\frac{Q_{i}-Q_{i-1}}{t_{i}-t_{i-1}}$

where $Q_{i}$ is discharge at time $t_{i}$ and $Q_{i-1}$ discharge at prior time $t_{i-1}$. Equation 3 relates to the rapid change in river discharge that can cause aquatic drift (up ramping) and stranding (down ramping). The indicator is dependent on the choice of the time step, and in most cases, hourly discharge intervals are sufficient (Pellaud 2007). In other cases where the high-head storage hydropower plants are at a short distance upstream of gauging stations, it is necessary to consider smaller time steps.

For comparison of the flow-ramping rates of different years, the calculated flow-ramping rates are classified into different categories, weighted by their time interval and divided by the total observation period, which is typically either a year or a month. In such a way, frequency, duration and intensity of flow ramping are assessed, and the yearly or monthly probabilities of occurrence for given flowramping rates are obtained. In the case of constant discharge over the observation period, for example, the statistical analysis of the second hydropeaking indicator would produce a probability of $P=100 \%$ for the zero flow-ramping rate.

\section{The Upper-Rhone River as a case study}

Description of the catchment area

The Upper-Rhone River basin is located in the southwestern part of the Swiss Alps and has an area of 
$5,244 \mathrm{~km}^{2}$. Some $14.3 \%$ of its catchment area is covered by glaciers. The natural annual flow regime is characterized by relatively low discharge during winter and high discharge during summer from snow and glacier melt, with floodwaters typically occurring in autumn. The basin mean annual precipitation is $1,435 \mathrm{~mm} /$ year (Schaedler and Weingartner 2001). The Upper-Rhone River (a seventhorder stream) has many tributaries, of which the most significant in scale are shown in Fig. 1. Two systematic river channelizations between 1863 and 1894 and between 1930 and 1960 were undertaken; $91.6 \%$ of the main channel length were affected by the channelizations and the total length of the river shoreline was reduced from 414 to $251 \mathrm{~km}$ (Weber et al. 2007). Despite these channelizations, recent floods in 1987, 1993 and 2000 identified several extensive portions of the river with inadequate flood protection. Hydroelectric power production from high-head storage schemes began in the Rhone valley in the early twentieth century with the construction of the Vouvry powerhouse (Lake Tanay) in 1902 (UVEK 2009). Most of the important high-head storage schemes were built between 1951 and 1975 (Loizeau and Dominik 2000) and the total storage capacity of the reservoirs increased from 97 to $1,155 \mathrm{Mio}^{3}$ in this period. After 1976, only a few small hydropower plants were added, although the capacity of some existing powerhouses was increased and one large dam was heightened (Mauvoisin) (UVEK 2009). In the year 2000, the total storage capacity of the hydropower reservoirs was approximately $1,193 \mathrm{Mio}^{3}$, a volume that corresponds to $21 \%$ of the mean annual flow at the outlet of the Rhone River near Lake Geneva (Porte du Scex gauging station). Water diversion for agricultural practices is also common in the region, but the effect on the flow regime is insignificant relative to hydropower plant utilization.

The cumulative operational discharge of all turbines in powerhouses along the Rhone River is $273 \mathrm{~m}^{3} \mathrm{~s}^{-1}$ (Fig. 2) which corresponds to $150 \%$ of mean annual discharge at Porte du Scex $\left(181 \mathrm{~m}^{3} \mathrm{~s}^{-1}\right.$, period 1905-2003) and to approximately four times the natural discharge during the winter months $\left(69.5 \mathrm{~m}^{3} \mathrm{~s}^{-1}\right.$, period 1905-1927). An overview of the reported modifications on the abiotic parameters of the Upper-Rhone River ecosystem due to hydropower storage plants is given in Table 1, which includes effects on water temperature (Meier et al. 2003; Meier and Wüest 2004), suspended sediment load (Loizeau and Dominik 2000), groundwater levels along the river (Fette et al. 2005) and oxygen content of Lake Geneva (Loizeau and Dominik 2000).

Gauging stations and available data

The data from five gauging stations (source: Swiss Federal Office for the Environment) were used for the current analysis, as illustrated in Fig. 1 and outlined in Table 2. Table 2 shows particularly that catchment area and natural mean annual discharge of the Vispa River, which is one of the largest tributaries of the Upper-Rhone River, are of the same order of magnitude as catchment area and mean annual discharge of the Rhone River at Brig. Systematic flow records at a minimum 1-h observation interval were used in the analysis between 1974 to 2008, as summarized in Table 3. The 1907 discharge flow used as the hydrologic reference pre-anthropogenic influence was established by the reconstruction of the record of the downstream gauge
Fig. 1 Overview of the catchment area. Main dams, rivers and towns are shown as well as gauging stations and power plants of the high-head storage schemes. Gauging stations $(\downarrow)$ from upstream to downstream: Brig, Vispa (on Vispa River), Sion, Branson (close to Martigny) and Porte du Scex (close to Lake Geneva). Powerhouses (o) from upstream to downstream: Bitsch, Stalden \& Ackersand (on Vispa River), Steg, Chippis (Navisence), St. Léonard, Chandoline, Nendaz \& Bieudron, Riddes, Fully, La Batiaz, Vernayaz, Miéville and Vouvry

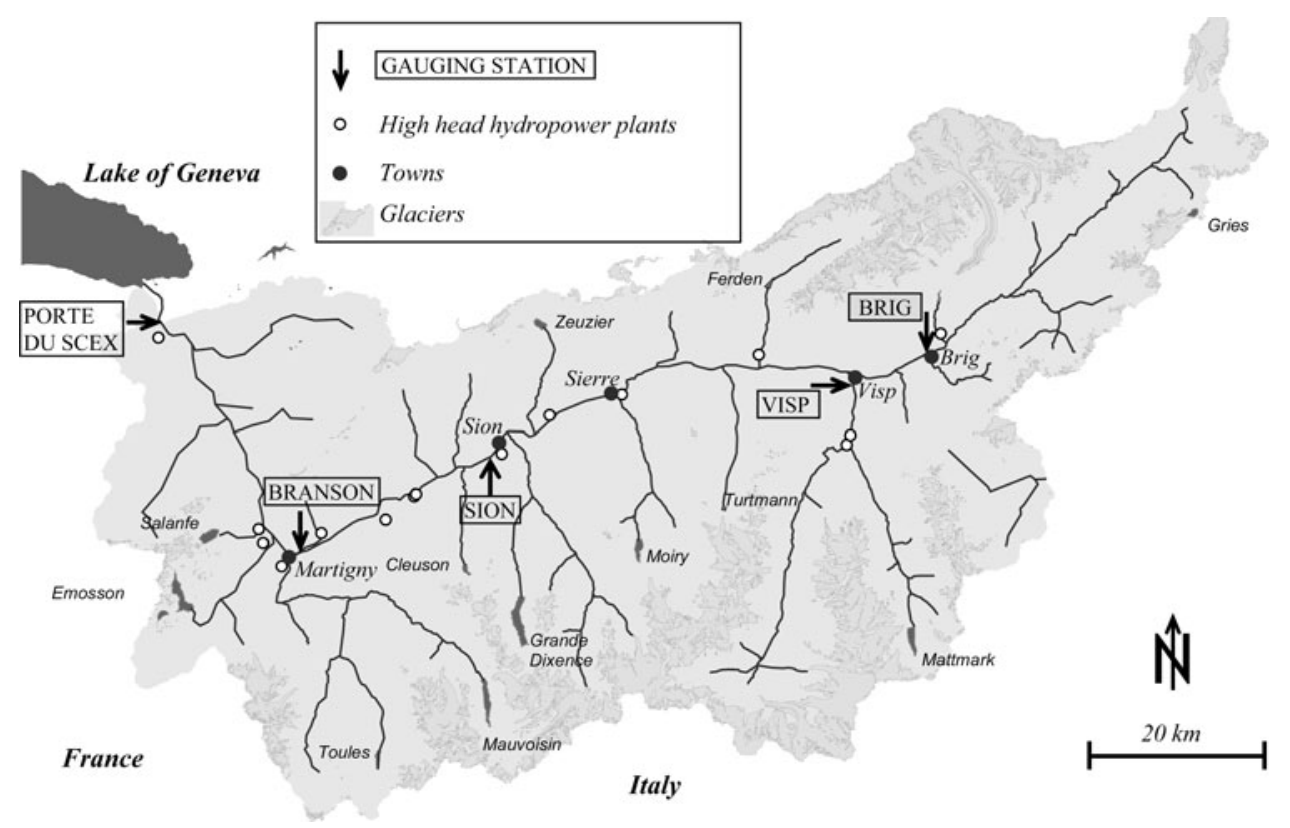




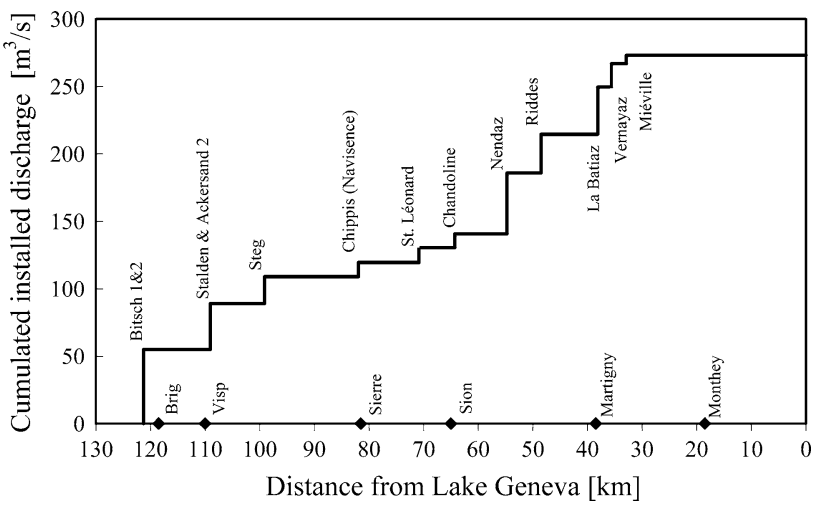

Fig. 2 Increase in the cumulated installed discharge of turbines of the high-head hydropower schemes from upstream to downstream on the Upper-Rhone River

station Porte du Scex from current systematic readings and historical rating curves.

To examine the natural flow regimes in water courses where hydropeaking occurs, hydrologic models were developed for each catchment region and calibrated to the current conditions, including the influence of hydropower schemes. After this calibration, the hydropower schemes were decoupled from the model, which was then considered representative of the natural flow regimes. For this analysis, the hydrological runoff model built by Jordan
(2007) and Jordan et al. (2006) was employed, which allows for the integration of rainfall, varying temperature, evapo-transpiration, glacier melt, snow pack constitution and melt, soil infiltration and runoff. The altimetric temperature gradient is considered by subdividing each basin into elevation bands. This allows segregating rain from snowfall. The model has been developed with the goal to optimize the routing effects of large reservoirs during high floods (see Jordan 2007 for more details). Furthermore, it can also reproduce the hydrographs of the river without considering hydropower schemes. This allowed us to reconstruct the pre-anthropogenic situation and to determine the two hydropeaking indicators for each gauging station based on calculated hydrographs' hourly values.

\section{Results and discussion}

Discharge hydrographs with and without high-head storage schemes

The discharge hydrographs and the flow-ramping rates for 2 weeks in August and October of 1907 and 2003, corresponding to the pre- and post-anthropogenic situation, are shown in Fig. 3 for the most downstream gauge station at Porte du Scex.

Table 1 Effect of the capacity of reservoirs and the installed discharge at the high-head hydropower plants on diverse parameters of the Rhone River

\begin{tabular}{|c|c|}
\hline Total capacity of the reservoirs & Total installed discharge at the hydropower plants \\
\hline Modification of the monthly mean discharge & Increase of the flow-ramping rates (Meile et al. 2005) \\
\hline $\begin{array}{l}\text { Increase of the daily discharge in winter and decrease in } \\
\text { summer (Loizeau and Dominik 2000) }\end{array}$ & $\begin{array}{l}\text { Modification of the daily water temperatures (Meier and } \\
\text { Wüest 2004) }\end{array}$ \\
\hline Diminished floods (Raboud et al. 2001) & $\begin{array}{l}\text { Modification on the daily evolution of suspended sediment } \\
\text { concentrations (Loizeau and Dominik 2000) }\end{array}$ \\
\hline Dominik 2000) by retention in reservoirs & \multirow{2}{*}{$\begin{array}{l}\text { Modification of the daily discharge hydrograph (Meile et al. } \\
\text { 2005) and all derived parameters such as flow velocities, } \\
\text { water levels and bed shear stress }\end{array}$} \\
\hline $\begin{array}{l}\text { Modification of the mean annual and the mean monthly water } \\
\text { temperatures (Meier and Wüest 2004) }\end{array}$ & \\
\hline
\end{tabular}

Table 2 Characteristics of the sub-catchments of the analyzed gauging stations in the Upper-Rhone River catchment (see also Fig. 1)

\begin{tabular}{lrlllcc}
\hline $\begin{array}{l}\text { Gauging station } \\
\text { sub-catchment }\end{array}$ & $\begin{array}{l}\text { Area } \\
\left(\mathrm{km}^{2}\right)\end{array}$ & $\begin{array}{l}\text { Mean altitude } \\
(\mathrm{m} . \text { a.s.1. })\end{array}$ & $\begin{array}{l}\text { Glacier } \\
\text { cover }(\%)\end{array}$ & $\begin{array}{l}\text { Mean annual discharge } \\
\left(\text { since 1976) }\left(\mathrm{m}^{3} \mathrm{~s}^{-1}\right)\right.\end{array}$ & $\begin{array}{l}\text { Cumulated design discharge } \\
\text { of all storage power } \\
\text { plants }\left(\mathrm{m}^{3} \mathrm{~s}^{-1}\right)\end{array}$ & $\begin{array}{l}\text { Cumulated reservoir } \\
\text { capacity }\left(\text { Mio } \mathrm{m}^{3}\right)\end{array}$ \\
\hline Rhone-Brig & 913 & 2,350 & 29 & 43.2 & 55.00 & 140.75 \\
Rhone-Sion & 3,349 & 2,310 & 18.4 & 109.3 & 214.50 & 302 \\
Rhone-Branson & 3,728 & 2,250 & 16.8 & 142.2 & 273.00 & 885 \\
Rhone-Porte du Scex & 5,220 & 2,130 & 14.3 & 190.8 & 34.00 & 1,186 \\
Vispa-Visp & 778 & 2,660 & 29.5 & $17.9^{\mathrm{a}}$ & 99.9
\end{tabular}

${ }^{a}$ Mean annual discharge from this station is highly influenced by water diversion towards the Grande Dixence reservoir. Mean annual discharge before the construction of the Grande Dixence reservoir was $26.6 \mathrm{~m}^{3} \mathrm{~s}^{-1}$ 
Table 3 Available data for the flow regime analysis of the different sub-catchments

\begin{tabular}{|c|c|c|c|}
\hline \multirow[t]{2}{*}{ Gauging station } & \multicolumn{2}{|c|}{ Data from gauging stations } & \multirow{2}{*}{$\begin{array}{l}\text { Data from runoff model } \\
\text { Discharge hydrograph }\end{array}$} \\
\hline & Mean daily discharge & Discharge hydrograph & \\
\hline Rhone-Brig & $1916-2003$ & 1974-2003 & 1993,2000 \\
\hline Rhone-Sion & $1916-2003$ & $1974-2003$ & 1993,2000 \\
\hline Rhone-Branson & $1941-2003$ & 1974-2003 & 1993,2000 \\
\hline Rhone-Porte du Scex & $1905-2003$ & $1907^{\mathrm{b}}, 1974-2003$ & 1993,2000 \\
\hline Vispa-Visp & $1903-2003$ & 1974-2003 & 1993,2000 \\
\hline
\end{tabular}

${ }^{a}$ Hydrograph obtained from a hydrological runoff model (see Jordan 2007 for details). The natural hydrographs have been simulated by decoupling of all existing hydropower schemes from the runoff model

${ }^{b}$ Hydrograph obtained from level measurements transformed into discharge using the rating curve of the year 1907 at Porte du Scex
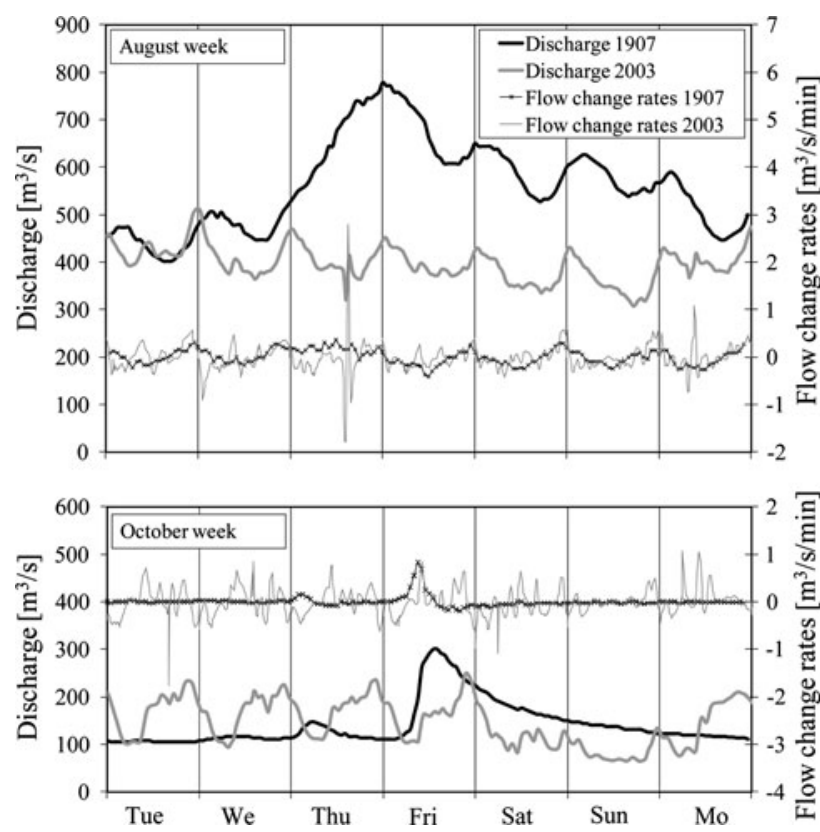

Fig. 3 Above weekly hydrograph at Porte du Scex for a week in August (1907 and 2003). High snow and glaciermelt discharge were observed during this summer week in the year 1907. Flow-ramping rates are indicated on the right $y$ axis. Below weekly hydrograph at Porte du Scex for a week in October (1907 and 2003). A small flood was observed during this week in the year 1907

The week considered in August 1907 was characterized by a summer flood ranging between the 5- and 10-year return period. The flow-ramping rates for the August week of 1907 show a diurnal cycle, which was also observed for the August week in the year 2003. The effects of hydropeaking in August of 2003 are hardly perceptible in the hydrograph; however, turbine operation has been prescribed to manage the natural flow, as indicated by the flow-ramping rates. The observation week in October 1907 was characterized by a small flood with a return period of $<1$ year. Conversely, the observation week in October, 2003 was strongly influenced by hydropeaking, as shown in Fig. 3. Several daily discharge peaks are visible. The most important peak of $230 \mathrm{~m}^{3} \mathrm{~s}^{-1}$ arrives at Porte du Scex around 8 PM. The minimum daily flow of about $100 \mathrm{~m}^{3} \mathrm{~s}^{-1}$ occurred in the early morning. Up and down ramping rates during the observation week in October were in general much higher in 2003 than in 1907. For the natural flood conditions of October 1907, only the maximum up-ramping rate $\left(+0.8 \mathrm{~m}^{3} \mathrm{~s}^{-1} \mathrm{~min}^{-1}\right.$ corresponding to a variation of the water-level of $+0.34 \mathrm{~m} / \mathrm{h}$ ) and down-ramping rate $\left(-0.2 \mathrm{~m}^{3} \mathrm{~s}^{-1} \mathrm{~min}^{-1}\right.$ corresponding to a variation of the water-level of $-0.08 \mathrm{~m} / \mathrm{h}$ ) approach those occurring daily, due to turbine operations, in 2003. In effect, the 2003 conditions cause several small floods daily.

Discharge hydrograph comparisons for the entire 1907 and 2003 calendar years revealed the following: (1) In 1907, daily fluctuations occurred during the fair weather months of May through October. Conversely, the 2003 hydrograph revealed daily fluctuations over the entire year with the exception of weekends and holidays where hydropower demand was lower. (2) In 1907, from May to October only one daily peak occurred, typically between 3 a.m. and 6 a.m. resulting from a combination of snowmelt and glacier melt. For the same months in 2003, several daily discharge peaks are recorded, corresponding to the time shifted arrivals of turbine operation peaks from the various power plants ( 3 a.m., 6 a.m., 9 a.m. or between 12 a.m. and 3 p.m.). Snowmelt and glacier melt were additive responses to the turbine operations during the summer months of 2003. (3) Periods of fair weather with high temperatures in 1907 lead to high discharges occurring during day and night (lag-time responses from the alpine regions). Similar meteorological conditions in 2003 decreased the effects of hydropeaking, as the natural daily cycle dominates turbine operation cycle. (4) Days with small and relatively constant discharge during winter months, such as observed in 1907 before the construction of hydropower plants, no longer occurred in 2003 due to hydropeaking. 
Evolution of the mean annual discharge over the observation period

Figure 4 shows the evolution and fluctuation of the mean annual discharge in Brig, Branson and Porte du Scex. The area of the natural catchment at Porte du Scex has been practically unchanged by anthropogenic activities (Margot et al. 1992). Less than $1 \%$ of the mean annual discharge from this catchment is diverted into neighboring catchment areas, namely $0.08 \mathrm{~m}^{3} \mathrm{~s}^{-1}$ since 1949 from Totensee to the Aare river catchment and $1.2 \mathrm{~m}^{3} \mathrm{~s}^{-1}$ since 1966 from Griessee to the Maggia river catchment. Approximately $2.6 \mathrm{~m}^{3} \mathrm{~s}^{-1}$ has been stream-captured through the Emosson reservoir into the Upper-Rhone River catchment since 1973 from the Arve catchment in France (source: HadesHydrological Atlas of Switzerland).

The mean annual discharge at Porte du Scex $\left(5,220 \mathrm{~km}^{2}\right)$ has a statistically significant increasing trend of $0.151 \%$ per year (Fig. 4). A significance level of $10 \%$ was satisfied using the Mann-Kendall and Spearman's Rho tests (Kundzewicz and Robson 2000). The increase in annual discharge can be explained by a combination of long-term changes in precipitation, temperature and evaporation rates (Schaedler 1987; Schaedler and Weingartner 2001; Birsan et al. 2004) that influenced the glacier volumes in each of the catchment areas. These glacier volumes have been steadily decreasing over the past century (Maisch et al. 2004), and the glacier melt contribution in the Upper-Rhone River basin has consequently increased (Schaedler and Weingartner 2001). Since the mean annual discharge of the Upper-Rhone River at Brig $\left(913 \mathrm{~km}^{2}\right)$ does not show the same increasing trend, the increase at the Rhone River outlet (Porte du Scex) is attributed to additional flow contributions derived from the densely glaciercovered catchments of the tributaries between Brig and Porte du Scex. This assumption is supported by the positive trend in the mean annual discharge at the gauging station

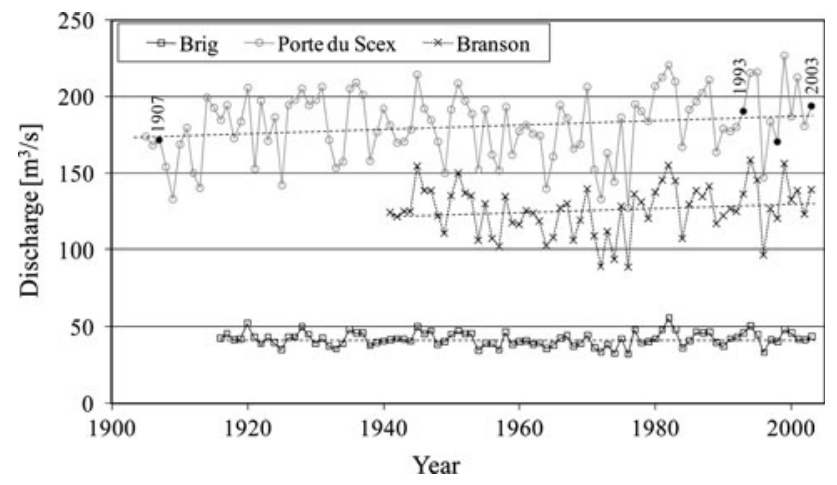

Fig. 4 Evolution of the mean annual discharge in the Upper-Rhone River at Brig, Branson, Porte du Scex

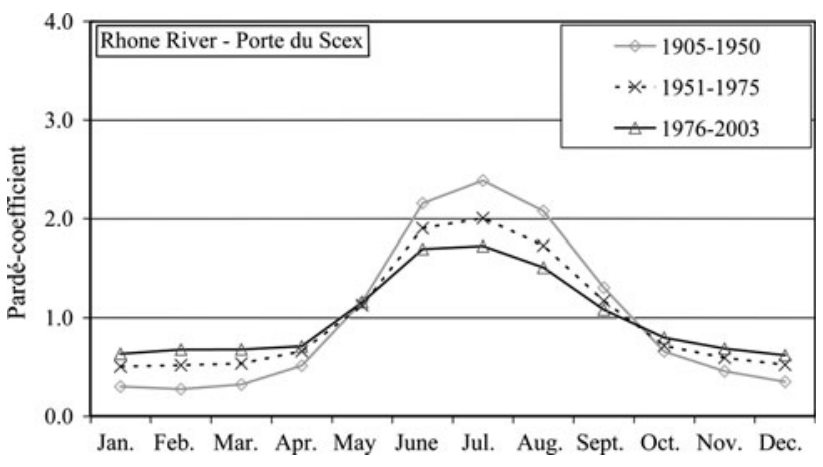

Fig. 5 Mean values of the Pardé-coefficients on the Rhone River at Porte du Scex before (1905-1950), during (1951-1975) and after (1976-2003) the construction of the main high-head storage power plants

Branson ${ }^{1}$ located approximately $40 \mathrm{~km}$ upstream of Porte du Scex.

Seasonal shift of water: Pardé-coefficients and flow duration curves

The averaged values of Pardé-coefficients at Porte du Scex are presented in Fig. 5 for the periods 1905-1950, 19511975 and 1976-2003. These values correspond to the pre-, during- and, post-construction periods of large reservoirs within the Rhone River catchment. After 1950, a significant redistribution of annual flow was observed from the summer to winter months. The mean monthly discharge has generally increased by $20-150 \%$ in winter (between October and April), while a decrease of $15-30 \%$ was observed in the summer (between June and September).

The Pardé-coefficients of the observation periods before and after high-head-storage hydropower-scheme construction at all gauging stations within the catchment quantify this seasonal transfer of water (Table 4). For the gauge stations Visp, Sion, Branson and Porte du Scex, which have natural annual flow regimes based upon glacier melt and glacier snowmelt, the annual distribution of flow has shifted towards regimes of higher winter and reduced summer flows (Table 4). In the case of the gauge station at Brig, only a minor change was observed since there is little storage volume of the reservoirs in this sub-catchment.

The observed relative increases of flow during winter and decreases during summer are also identified in the flow duration curves illustrated in Fig. 6. Comparison of the pre-construction period (1905-1950) and post-construction period (1976-2003) at the most downstream gauge at Porte

\footnotetext{
1 This value has been corrected in order to take into account the diversion from the Mauvoisin reservoir. Since 1956, on average $9.24 \mathrm{~m}^{3} \mathrm{~s}^{-1}$ are rejected by the Riddes powerhouse into the UpperRhone River upstream of Branson. Before 1956, the water joined the Rhone River downstream of Branson.
} 
Table 4 Mean Pardé coefficients for all gauging stations of the Upper-Rhone River catchment for the period before and after the construction of the main high-head storage hydropower plants

\begin{tabular}{|c|c|c|c|c|c|c|c|c|c|c|c|c|}
\hline \multirow[t]{2}{*}{ Gauging station } & \multicolumn{12}{|c|}{ Month } \\
\hline & 1 & 2 & 3 & 4 & 5 & 6 & 7 & 8 & 9 & 10 & 11 & 12 \\
\hline \multicolumn{13}{|l|}{ Brig } \\
\hline 1916-1950 & 0.19 & 0.17 & 0.20 & 0.36 & 1.00 & 2.16 & 2.74 & 2.42 & 1.51 & 0.64 & 0.33 & 0.22 \\
\hline 1976-2003 & 0.21 & 0.19 & 0.24 & 0.38 & 1.07 & 2.15 & 2.68 & 2.39 & 1.30 & 0.72 & 0.34 & 0.25 \\
\hline Change (\%) & 11 & 12 & 24 & 6 & 7 & -1 & -2 & -1 & -14 & 14 & 4 & 11 \\
\hline \multicolumn{13}{|l|}{ Sion } \\
\hline 1916-1950 & 0.24 & 0.22 & 0.24 & 0.37 & 0.98 & 2.18 & 2.64 & 2.34 & 1.47 & 0.65 & 0.39 & 0.28 \\
\hline 1976-2003 & 0.44 & 0.45 & 0.46 & 0.53 & 1.12 & 1.96 & 2.22 & 1.93 & 1.16 & 0.76 & 0.53 & 0.45 \\
\hline Change $(\%)$ & 83 & 107 & 88 & 42 & 15 & - & - & - & - & 18 & 34 & 59 \\
\hline \multicolumn{13}{|l|}{ Branson } \\
\hline 1941-1950 & 0.27 & 0.27 & 0.30 & 0.49 & 1.01 & 2.05 & 2.44 & 2.30 & 1.53 & 0.60 & 0.43 & 0.31 \\
\hline 1976-2003 & 0.61 & 0.66 & 0.63 & 0.62 & 1.04 & 1.71 & 1.86 & 1.71 & 1.16 & 0.78 & 0.65 & 0.57 \\
\hline Change $(\%)$ & 125 & 147 & 106 & 26 & 4 & - & - & - & - & 30 & 52 & 84 \\
\hline \multicolumn{13}{|l|}{ Porte du Scex } \\
\hline 1905-1950 & 0.30 & 0.27 & 0.32 & 0.51 & 1.16 & 2.16 & 2.38 & 2.08 & 1.30 & 0.66 & 0.46 & 0.35 \\
\hline 1976-2003 & 0.63 & 0.68 & 0.68 & 0.71 & 1.16 & 1.69 & 1.72 & 1.51 & 1.08 & 0.80 & 0.69 & 0.62 \\
\hline Change (\%) & 111 & 147 & 111 & 39 & 0 & - & - & - & - & 21 & 50 & 77 \\
\hline \multicolumn{13}{|l|}{ Visp $^{a}$} \\
\hline 1903-1950 & 0.15 & 0.13 & 0.14 & 0.24 & 0.71 & 2.05 & 2.99 & 2.90 & 1.61 & 0.53 & 0.28 & 0.18 \\
\hline 1976-2003 & 0.60 & 0.62 & 0.59 & 0.60 & 0.92 & 1.55 & 2.00 & 1.96 & 1.14 & 0.79 & 0.64 & 0.55 \\
\hline Change (\%) & 307 & 372 & 308 & 150 & 29 & -24 & -33 & -32 & -29 & 48 & 128 & 203 \\
\hline
\end{tabular}

${ }^{a}$ For the sub-catchment of the gauging station at the Vispa River, the increases and decreases of the Pardé coefficients are the result of two effects: (1) the construction of the Mattmark dam and (2) the diversion of water into the Grand Dixence reservoir

du Scex reveals a decrease in the annual maximum daily discharge from 682 to $566 \mathrm{~m}^{3} \mathrm{~s}^{-1}$. Compared to the pre1950 period, the mean daily discharge is lower during 117 days, mainly in summer and higher during 247 days, mainly in winter. The relative reduction of the mean daily discharge during the 117 days reaches a maximum of $-24 \%$, while the relative increase during the remaining 247 days is at maximum $+113 \%$. With respect to hydraulic geometry, the parameters of flow depth, velocity and bed shear stress are more significantly modified by the increase in mean daily discharge during the winter than the decreases in flow during the summer. However, the decrease in daily mean discharges in summer can influence bed material transport and the frequency of armor layer break-up, and thus change channel morphology.

Daily flow fluctuations: hydropeaking indicator $\mathrm{HP}_{1}$

The monthly averaged values of the hydropeaking indicator $\mathrm{HP}_{1}$ obtained for the year 1993 are presented for all gauging stations in Fig. 7 (above, upper band). They are compared with the values of the hydrology for the reference year 1907, measured at Porte du Scex, in addition to the reconstructed values for the year obtained by a runoff simulation without hydropower schemes (1993 HM). Statistical analysis of the daily values of $\mathrm{HP}_{1}$ identified the non-exceedance probability of a certain threshold value (Fig. 7, below). For example, $\mathrm{HP}_{1}$ remained below 0.5 for $98 \%$ of the days under unregulated flow conditions (1907 and $1993 \mathrm{HM}$ ) at all gauging stations of the Upper-Rhone River catchment. Under hydropeaking conditions for the year 1993, the indicator was below 0.5 only during 53$59 \%$ of the days at the gauging stations at Brig, Sion, Branson and Porte du Scex, and below the same threshold for only $11 \%$ of the days at the Vispa River gauge. In the contemporary channelized Upper-Rhone River, the value of $\mathrm{HP}_{1}=0.5$ corresponded to typical water level variations of $0.22,0.45,0.62$ and $0.63 \mathrm{~m}$ per day at Brig, Sion, Branson and Porte du Scex, respectively.

The monthly average values of $\mathrm{HP}_{1}$ were generally lower during winter than summer, and always below 0.25 under unregulated flow conditions (1907 and 1993 HM). Under hydropeaking conditions (1993), the monthly average values of $\mathrm{HP}_{1}$ almost always exceeded 0.25 with maximum values between 0.5 and 0.75 for the period of September/October to March/April (Fig. 7, above). It was further observed that under the natural flow conditions, all curves of the non-exceedance probability had similar 


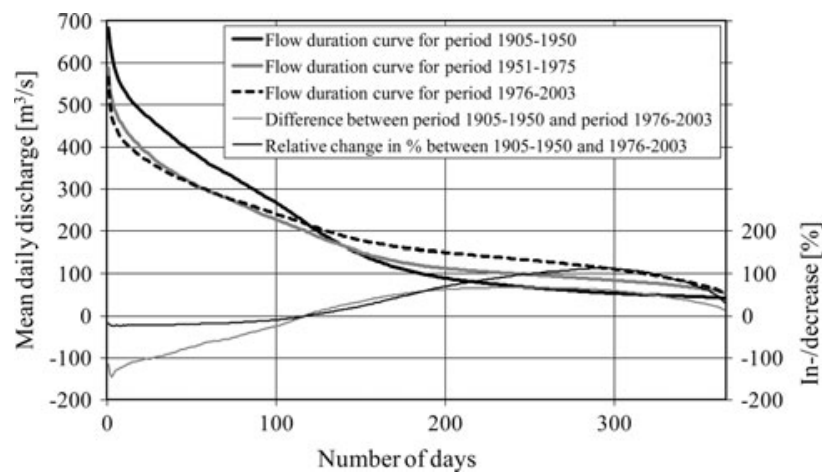

Fig. 6 Flow duration curves for the mean daily discharge at Porte du Scex for the periods before (1905-1950), during (1951-1975) and after (1976-2003) the construction of the main high-head storage power plants. Absolute and relative change is compared for the period 1976-2003 with the period 1905-1950

values (Fig. 7, below). The non-exceedance probability of $\mathrm{HP}_{1}$ seems to be an inherent characteristic of the natural discharge regime, since all studied gauging stations have a natural annual flow regime of the glacier melt or glaciersnowmelt type. It might be possible to determine reference curves of $\mathrm{HP}_{1}$ for all flow regimes occurring in Swiss rivers as done for the Pardé-coefficients (Weingartner and Aschwanden 1992; Pfaundler et al. 2007).

Flow-ramping rates: hydropeaking indicator $\mathrm{HP}_{2}$

Figure 8 illustrates the flow-ramping rates along the UpperRhone River from Sion to Porte du Scex. The probability to observe high up- and down-ramping rates increases from upstream to downstream, which is mainly the effect of the release of water from the largest powerhouses situated downstream of Sion. The natural routing effect in the channelized Upper-Rhone River is not able to overcome the increasing influence of the power plants along the river.

The distribution curves of the flow-ramping rates, over the period of a month, are given in Fig. 9. Under the natural conditions of the year 1907, three groups can be identified, namely: winter months having a high probability to observe low flow-ramping rates, spring and autumn months with intermediate flow-ramping rates and summer months with higher flow-ramping rates. The increases in flow-ramping rates in the non-winter months are due to daily cycles in the discharge caused by snow and glacier melt. The timing of distribution curves corresponding to winter, spring/autumn and summer months within a specific year may be slightly different from 1907 depending on meteorological conditions. However, the distinction into winter, spring-autumn and summer months should be relatively consistent over a multi-year period. For the year 1998, which includes the effect of hydropeaking, the distribution curves of flow-ramping rates were quite similar

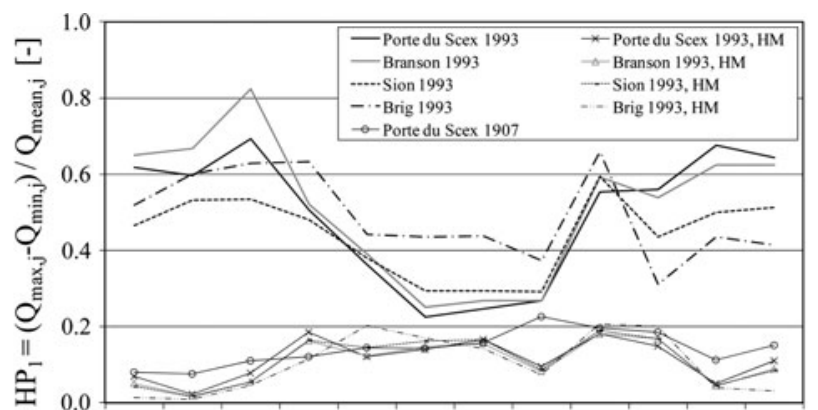

Jan. Feb. Mar. Apr. May June Jul. Aug. Sept. Oct. Nov. Dec.

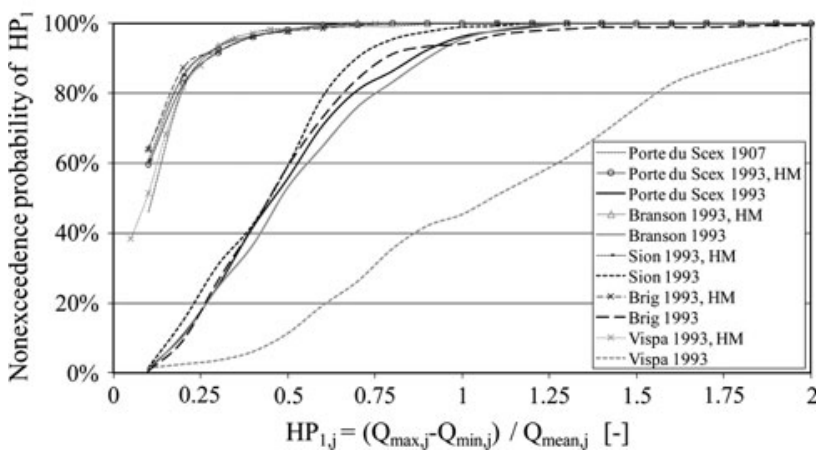

Fig. 7 Above daily discharge fluctuations of the Rhone River at Porte du Scex, Branson, Sion, Brig and of the Vispa River in Visp. Mean values per month of the hydropeaking indicator $\mathrm{HP}_{1}$ for different years. Below statistical analysis of the daily values of the hydropeaking indicator $\mathrm{HP}_{1}$ for the year 1993 (all gauging stations) and 1907 (Porte du Scex). Years indicated with HM means that the natural flow regime has been reconstructed by a hydrological runoff model

for all months of the year. The seasonal variability has been eliminated and replaced by the daily variability of turbine operation.

\section{Effect of a multipurpose compensation basin on the hydropeaking indicators}

Several alternatives are available for the technical mitigation of hydropeaking (Baumann and Klaus 2003; Meile 2006). Among the various methods, the construction of compensation basins are often the most effective solution for satisfying hydroelectric demand while enhancing downstream aquatic ecology. The combination of compensation basins with hydroelectric projects is commonly referred to as multipurpose projects. Such a solution was studied on the Upper-Rhone River in the region between Sion and Martigny by installing a multipurpose compensation basin having a surface of $1.0 \mathrm{~km}^{2}$ and a useful storage volume of 4 Mio $\mathrm{m}^{3}$ (Heller et al. 2005, 2007). In addition to restoring a more ecologically amenable flow regime, the multipurpose basin is controlled by a $10 \mathrm{MW}$ run-of-river hydropower plant and can produce $40 \mathrm{GWh}$ of electricity per annum. The compensation basin also 


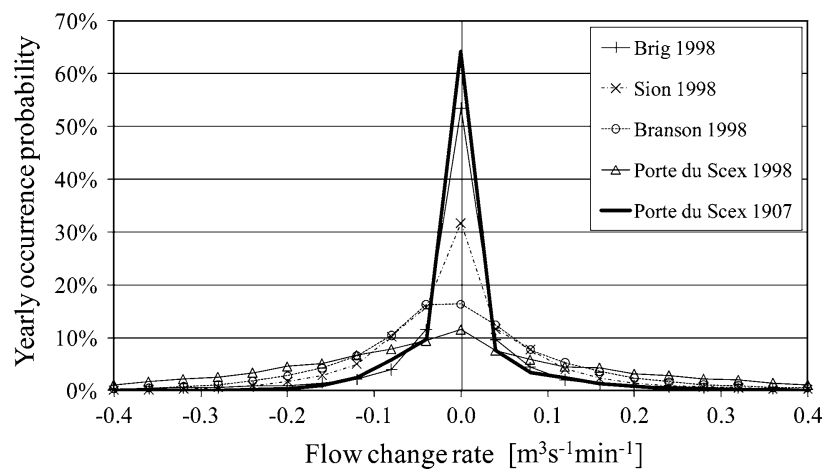

Fig. 8 Hydropeaking indicator $\mathrm{HP}_{2}$. Yearly probability of occurrence ( $y$ axis) of flow-ramping rates ( $x$ axis) on the Rhone River at Porte du Scex for 1907 and Brig, Sion, Branson and Porte du Scex for 1998

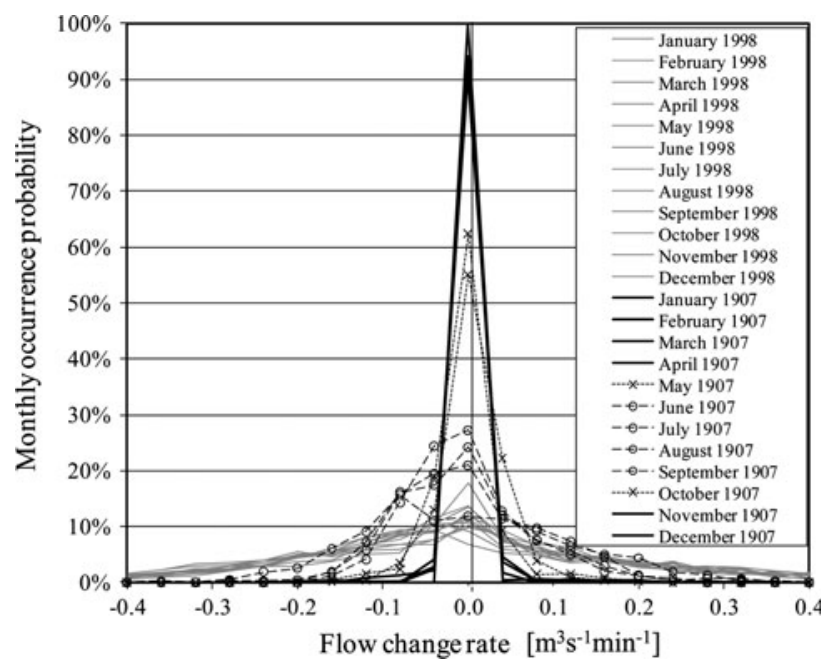

Fig. 9 Hydropeaking indicator $\mathrm{HP}_{2}$. Monthly probability of occurrence ( $y$ axis) of flow-ramping rates ( $x$ axis) on the Rhone River at Porte du Scex for 1907 and 1998. Black winter months NovemberApril, spring-autumn months May and October and summer months June to September 1907. Grey all months of 1998

provides flood-flow attenuation in severe conditions, and facilitates the creation of biotopes and leisure activities. By storing water in such a compensation basin during the peak energy production of the high-head storage power plants and releasing it during low-energy demand periods at night and on weekends, the variation in water levels in the downstream reach of the Rhone River can be limited to $6 \mathrm{~cm} / \mathrm{h}$ in winter and $15 \mathrm{~cm} / \mathrm{h}$ in summer. Additionally, the absolute water level fluctuations in the downstream reach can be maintained below $30 \mathrm{~cm} /$ day in winter and $70 \mathrm{~cm} /$ day in summer. These two constraints, to which floods are obviously excluded, can mitigate the negative ecological effects of the hydropeaking in the downstream reach of the Upper-Rhone River (Pellaud, 2007). The corresponding weekly water-level fluctuations in the compensation basin reach $2.5 \mathrm{~m}$ in winter and less than $1 \mathrm{~m}$ in summer (when the basin can be used for leisure activities.

The consequence of the restoration of a more ecologically beneficial flow regime in the downstream reach of the multipurpose reservoir can be shown using the hydropeaking indicators $\mathrm{HP}_{1}$ and $\mathrm{HP}_{2}$ at the gauging station at Branson. For the year 1993, Fig. 10 compares the two hydropeaking indicators under three different situations, namely the actual situation without the compensation basin, natural conditions reconstructed with the hydrological runoff model of the river basin, and the situation with the multipurpose compensation basin. With a multipurpose basin, the hydropeaking indicator $\mathrm{HP}_{1}$ can be kept below 0.5 for $84 \%$ of the days compared to $53 \%$ without the basin (Fig. 10, above). Under natural conditions in 1993, simulated with the runoff model, the hydropeaking indicator would have been below 0.5 for $98 \%$ of the days. Furthermore, the probability of occurrence of important up- and down-ramping rates is also significantly reduced by the compensation basin (Fig. 10, below). It may be concluded that the multipurpose basin is an efficient measure to mitigate the adverse effects of hydropeaking without endangering the economic sustainability of the storage power plants.

\section{Summary and conclusions}

Similar to many rivers in alpine regions, the Upper-Rhone River has undergone considerable anthropogenic changes during the twentieth century. River morphology was degraded during two systematic river channelizations, leading to a significant decrease in river shoreline length. Since the 1950s, the natural flow regime of the catchment has been altered by multiple reservoir and high-head hydropower plant construction initiatives. Alterations to the flow regime have resulted in a partial transfer of water from the summer to winter seasons with an increased annual frequency of daily peak discharge events resulting from hydropeaking.

Sustainable river-restoration projects should address simultaneously river morphology, water quality and flow regime. Thus, when considering ecological restoration of riparian corridors, mitigation of hydropeaking must be discussed. Non-natural, sub-daily flow fluctuations can affect the integrity of river ecosystems in the same way as the importance, duration, frequency and timing of floods or low flow periods (Poff et al. 1997; Richter et al. 1997).

The effect of high-head storage hydropower schemes on the flow regime of alpine catchments can be effectively evaluated using the proposed indicators: the Pardé-coefficients as an indicator for the seasonal water transfer, a first hydropeaking indicator describing the sub-daily flow 

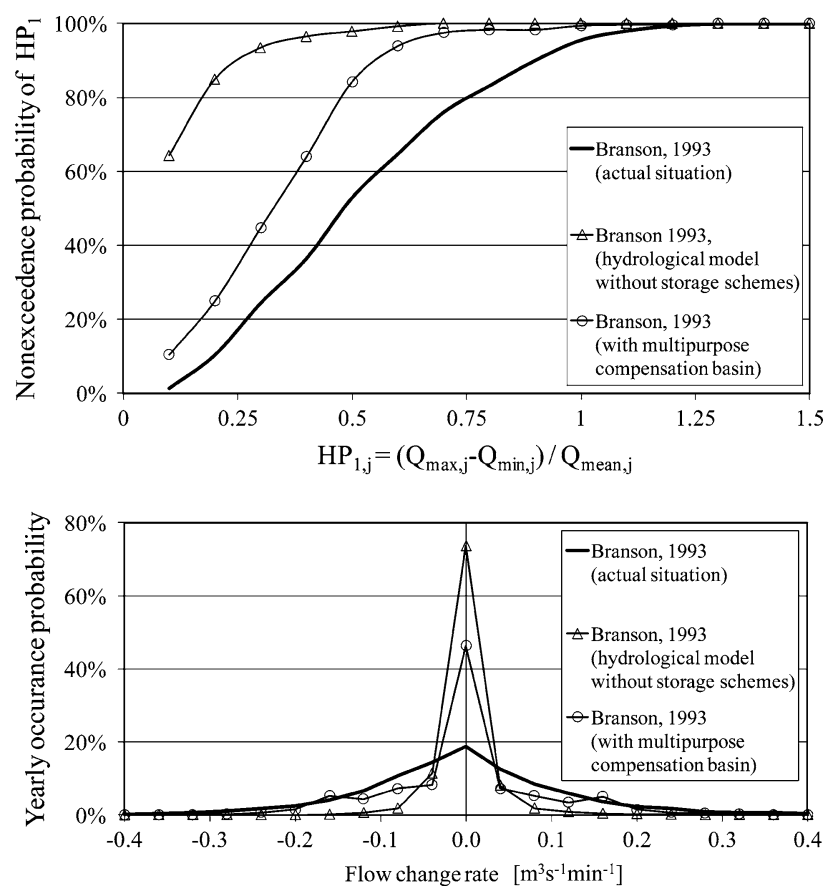

Fig. 10 Effect of a multipurpose compensation basin on the hydropeaking indicators $\mathrm{HP}_{1}$ (above) and $\mathrm{HP}_{2}$ (below). The actual situation is compared to the natural conditions simulated by the hydrological model without storage schemes and the situation with a multipurpose compensation basin

fluctuations, and a second hydropeaking indicator characterizing the frequency and intensity of flow ramping. The indicators are complementary to other indicators used for the description of flow regimes (Richter et al. 1996; Baker et al. 2004, Archer and Newson 2002) but specifically adapted to rivers in catchments with high-head storage hydropower schemes. The two proposed hydropeaking indicators are also appropriate to evaluate the effects of mitigation measures against hydropeaking.

In the case study on the Upper-Rhone River catchment, the results show that the inter-seasonal transfer of water by the reservoirs at high altitude from the summer season into winter season, as identified by the Pardé-coefficients, cannot be realistically mitigated due to an important storage volume of $1,193 \mathrm{Mio} \mathrm{m}^{3}$ (21\% of the annual flow). On the other hand, results show that, even if complete mitigation of the non-natural, sub-daily flow fluctuations is not possible due to socio-economic constraints, partial restoration of a more natural flow regime can be evaluated with the proposed hydropeaking indicators. Analysis using these hydropeaking indicators showed quantitatively the beneficial effects of a multipurpose compensation basin that partially restores the natural daily flow regime of the Upper-Rhone river.

Acknowledgments The work was supported by the Swiss Federal Office for Environment in the framework of the Rhone-Thur research project. Frederic Loup analyzed some of the flow data during his semester project and Marion Bourgeois simulated natural discharge data in the framework of her Master's thesis work. The authors acknowledge also the valuable comments of Bill Annable and two anonymous reviewers.

\section{References}

Archer D, Newson M (2002) The use of indices of flow variability in assessing the hydrological and instream habitat impacts of upland afforestation and drainage. J Hydrol 268:244-258

Arthington AH, Naiman RJ, McClain ME, Nillson C (2010) Preserving the biodiversity and ecological services of rivers: new challenges and research opportunities. Freshw Biol 55:1-16

Baker DB, Richards RP, Loftus TT, Kramer JW (2004) A new flashiness index: characteristics and applications to Midwestern rivers and streams. J Am Water Resour Assoc 40:503-522

Baumann P, Klaus I (2003) Gewässerökologische Auswirkungen des Schwallbetriebes. Mitteilungen zur Fischerei Nr. 75, Bundesamt für Umwelt. Wald und Landschaft, Bern (in German and French)

Birsan M-V, Molnar P, Pfaundler M, Burlando P (2004) Trends in schweizerischen Abflussmessreihen. Wasser Energie Luft-Eau énergie air 96:29-38

Black AR, Rowan JS, Duck RW, Bragg OM, Clelland BE (2005) DHRAM: a method for classifying river flow regime alterations for the EC Water Framework Directive. Aquatic Conserv Marine Freshw Ecosyst 15:427-446

Brittain JE, Saltveit SJ (1989) A review of the effect of river regulation on mayflies (ephemeroptera). Regul Rivers Res Manage 3:191-204

Bunn SE, Arthington AH (2002) Basic principles and ecological consequences of altered flow regimes for aquatic biodiversity. Environ Manage 30:492-507

Céréghino R, Lavandier P (1998) Influence of hydropeaking on the distribution and larval development of the plecoptera from a mountain stream. Regul Rivers 14:297-309

Céréghino R, Cugny P, Lavandier P (2002) Influence of intermittent hydropeaking on the longitudinal zonation patterns of benthic invertebrates in a mountain stream. Int Rev Hydrobiol 87(1):47-60

Cushman RM (1985) Review of ecological effects of rapidly varying flows downstream of hydroelectric facilities. North Am J Fish Manage 5:330-339

DETEC (2008) Federal Department for the Environment, Transport, Energy and Communications. The floods of 2005 in Switzerland. Synthesis report on the event analysis (also available in German, French and Italian)

EC (European Community) (2000) Water Framework Directive (2000/60/EC). Off J Eur Commun L 327:1-72

Fette M, Kipfer R, Schubert CJ, Hoehn E, Wehrli B (2005) Assessing river-groundwater exchange in the regulated Rhone river (Switzerland) using stable isotopes and geochemical tracers. Appl Geochem 20:701-712

Freeman MC, Bowen ZH, Bove KD, Irwin ER (2001) Flow and habitat effects on juvenile fish abundance in natural and altered flow regime. Ecol Appl 11:179-190

Gore JA (1985) The restoration of rivers and streams: theories and experience. Butterworth/Ann Arbor, Michigan

Halleraker JH, Saltveit SJ, Harby A, Arnekleiv JV, Fjeldstad HP, Kohler B (2003) Factors influencing stranding of wild juvenile brown trout (salmo trutta) during rapid and frequent flow decreases in an artificial stream. River Res Appl 19:589-603. doi: $10.1002 /$ rra. 752

Heller P, Bollaert E, Schleiss A (2005) Potential synergies of multipurpose run-of-river hydroelectric power plants. In: 
Proceedings XXXI IAHR Congress, Theme C, Seoul, Korea, 1116 September: 2121-2130

Heller P, Pellaud M, Bollaert E, Schleiss AJ, Schlaepfer R (2007) River rehabilitation through a multi-purpose reservoir. In: Proceedings XXXII IAHR Congress, Abstracts Volume 1, Venice, Italy, 1-7 July: 3 (full record on CD)

Jordan F (2007) Modèle de prévision et de gestion des crues : optimisation des opérations des aménagements hydroélectriques à accumulation pour la réduction des débits de crue. Thèse No 3711 de 1'Ecole polytechnique fédérale de Lausanne, Switzerland (also published as Communication No 29 of the Laboratory of Hydraulic Constructions, ISSN 1661-1179.)

Jordan F, Dubois J, Boillat JL, Schleiss A (2006) Prévision et gestion des crues par opérations préventives sur les retenues alpines. In: Proc., XXIIe Congrès des Grands Barrages, CIGB/ICOLD, Barcelone: 497-510

Jungwirth M, Muhar S, Schmutz S (2002) Re-establishing and assessing ecological integrity in riverine landscapes. Freshw Biol 47:867-887

Kundzewicz ZW, Robson A (2000) Detecting trend and other changes in hydrological data. World Climate Program-Water, WMO/ UNESCO, WCDMP-45. WMO/TD 1013, Geneva, Switzerland

Loizeau JL, Dominik J (2000) Evolution of the Upper-Rhone River discharge and suspended sediment load during the last 80 years and some implications for Lake Geneva. Aquatic Sci 62:54-67

Maisch M, Paul F, Kääb A (2004) Glacier parameters and their changes, 1850-2000. In: Hydrological Atlas of Switzerland, Plate 3.10, Department of Geography, Berne UniversityHydrology \& Swiss Federal Office for Water and Geology, Bern, Switzerland. (in German, French and Italian)

Malm Renöfält B, Jansson R, Nilsson C (2010) Effects of hydropower generation and opportunities for environmental flow management in Swedish riverine ecosystems. Freshw Biol 55:49-67

Margot A, Sigg R, Schädler B, Weingartner R (1992) Influence on rivers by water power stations and the lake control. Hydrological Atlas of Switzerland-Plate 5.31992

Meier W, Wüest A (2004) Wie verändert die hydroelektrische Nutzung die Wassertemperatur der Rhone? Wasser Energie Luft-Eau énergie air 96:305-309

Meier W, Bonjour C, Wüest A, Reichert P (2003) Modeling the effect of water diversion on the temperature of mountain streams. J Environ Eng 129:755-764. doi:10.1061/(ASCE)0733-9372 (2003)129:8(755)

Meile T., 2006. Hydropeaking on Watercourses. EAWAG news 61: 28-29 (translated from German)

Meile T, Schleiss A, Boillat JL (2005) Entwicklung des Abflussregimes der Rhone seit dem Beginn des 20. Jahrhunderts. Wasser Energie Luft-Eau énergie air 97:133-142

Olden JD, Poff NL (2003) Redundancy and the choice of hydrologic indices for characterizing streamflow regimes. River Res Appl 19:101-121. doi:10.1002/rra.700

Pardé M (1933) Fleuves et rivières. Armand Colin, Paris

Pellaud M (2007) Ecological response of a multi-purpose river development project using macro-invertebrates richness and fish habitat value. Thèse No 3807 de l'Ecole polytechnique fédérale de Lausanne, Laboratoire des Systèmes Ecologiques, Lausanne, Switzerland

Petts GE, Amoros C (eds) (1996) Fluvial Hydrosystems. Chapman and Hall, London

Pfaundler M, Dübendorfer C, Pfammatter R, Zysset A (2007) Methoden zur Untersuchung und Beurteilung der Fliessgewässer. Hydrologie-Abflussregime. Umwelt-Vollzug. Entwurf vom
Oktober 2007. Bundesamt für Umwelt, Bern, Switzerland. $104 \mathrm{pp}$

Poff NL, Allen JD, Bain MB, Karr JR, Prestegaard KL, Richter BD, Sparks RE, Stromberg JC (1997) The natural flow regime. A paradigm for river conservation and restoration. Bioscience 47:769-784

Poff NL, Richter BD, Arthington AH et al (2010) The ecological limits of hydrologic alteration (ELOHA): a new framework for developing regional environmental flow standards. Freshw Biol $55: 147-170$

Raboud PB, Dubois J, Boillat JL, Costa S, Pitteloud PY (2001) Projet Minerve-Modélisation de la contribution des bassins d'accumulation lors des crues en Valais. Wasser Energie Luft-Eau énergie air 93:313-317

Richter BD, Baumgartner JV, Powell J, Braun DP (1996) A method for assessing hydrologic alteration within ecosystems. Conserv Biol 10:1163-1174. doi:10.1046/j.1523-1739.1996.10041163.x

Richter BD, Baumgartner JV, Wigington R, Braun DP (1997) How much water does a river need? Freshw Biol 37:231-249. doi: 10.1046/j.1365-2427.1997.00153.x

Saltveit SJ, Halleraker JH, Arnekleiv JV, Harby A (2001) Field experiments on stranding in juvenile atlantic salmon (Salmo salar) and brown trout (Salmo trutta) during rapid flow decrease caused by hydropeaking. Regul Rivers Res Manage 17:609-622

Schaedler B (1987) Long water balance time series in the upper basins of four important rivers in Europe-indicators for climatic changes? IAHS Publ 168:209-219

Schaedler B, Weingartner R (2001) Components of the natural water balance 1961-1990. In: Hydrological Atlas of Switzerland, Plate 6.3, Department of Geography, Bern University-Hydrology \& Swiss Federal Office for Water and Geology, Bern, Switzerland (in German, French and Italian)

Schleiss A (2007) L'hydraulique suisse: Un grand potentiel de croissance par l'augmentation de la puissance. Bull SEV/VSE 2(07):24-29

Truffer B, Markard J, Bratrich C, Wehrli B (2001) Green electricity from Alpine hydropower plants. Mt Res Dev 21:19-24

Unfer G, Schmutz S, Wiesner C, Habersack H, Formann E, Komposch C, Paill W (2004) The effects of hydropeaking on the success of river-restoration measures within the LIFE-Project "Auenverbund Obere Drau". In: Proceedings of the fifth international symposium on ecohydraulics, Madrid, pp 741-746

UVEK (2009) Statistik der Wasserkraftzentralen in der Schweiz. Eidg. Depart. für Umwelt, Verkehr, Energie und Kommunikation UVEK, Bundesamt für Energie BFE (http://www.bfe. admin.ch)

Vibert R (1939) Répercussions piscicoles du fonctionnement par éclusées des usines hydroélectriques. Bulletin français de pisciculture 116 \& 117: 109-115 \& 137-155

Weber C, Peter A, Zanini F (2007) Spatio-temporal analysis of fish and their habitat: a case study on a highly degraded Swiss river system prior to extensive rehabilitation. Aquatic Sci 69:162-172. doi:10.1007/s00027-007-0912-3

Weingartner R, Aschwanden H (1992) Discharge regime-the basis for the estimation of average flows. In: Hydrological Atlas of Switzerland, Plate 5.2, Department of Geography, Bern University - Hydrology \& Swiss Federal Office for Water and Geology, Bern, Switzerland (in German, French and Italian)

Zwahlen R (2003) Identification, assessment and mitigation of environmental impacts of dam projects. In: Ambasht RS (ed) Modern Trends in Applied Aquatic Ecology. Kluwer, New York, pp 281-370 